\title{
Public Health in a Radioactive Age: Environmental Pollution, Popular Therapies, and Narratives of Danger in the Federal Republic of Germany, 1949-1970
}

\author{
Caitlin E. Murdock
}

\begin{abstract}
In the 1950s and 1960s, West German citizens found themselves living in a "radioactive age." The public learned that radiation exposure pervaded postwar society, not only from atomic testing but also from medical treatment, workplace exposures, and radium consumer goods. By 1970, West Germans—ranging from farmers and housewives, to physicians, scientists, and bureaucrats - had recast nuclear radiation from a technological wonder or health aid into a public health hazard. This article illustrates that anxieties about uncontrollable technology, ineffective institutions, disingenuous political leaders, and volatile citizens persisted from the 1950s to the 1970s, coexisting with optimism and progress, without truly subsiding in the 1960s, as historians often suggest. Further, it advocates taking those fears seriously, showing that they played a critical — and lasting — role in shaping public policy and state-society relations in the early Federal Republic.
\end{abstract}

In den 1950er und 1960er Jahren bemerkten westdeutsche Bürger, dass sie in einem "radioaktiven Zeitalter" lebten. Die Öffentlichkeit fand heraus, dass die Nachkriegsgesellschaft von Strahlenbelastung durchzogen war - nicht nur aufgrund von Atomtests, sondern auch wegen medizinischer Behandlungen, Exposition am Arbeitsplatz und Radium enthaltenden Konsumgütern. Bis zum Jahr 1970 hatten Westdeutsche - Bauern und Hausfrauen gemeinsam mit Physikern, Wissenschaftlern und Bürokraten - die radioaktive Strahlung von einem Wunder der Technologie und Gesundheitshilfe in eine Gefahr für die Gesundheit der Öffentlichkeit umgedeutet. Dieser Aufsatz zeigt, dass von den 1950er bis in die 1970er Jahre Ängste über unkontrollierbare Technologie, ineffiziente Institutionen, unaufrichtige politische Eliten und eine impulsive Bürgerschaft fortbestanden und mit Optimismus und Fortschritt koexistierten und auch in den 1960er Jahren nicht, wie Historiker oft behaupten, nachließen. Außerdem wird dafür plädiert, diese Ängste ernst zu nehmen, indem gezeigt wird, dass diese eine erhebliche und bleibende - Rolle dabei spielten, wie sich die öffentliche Politik und die Beziehungen innerhalb der Staatsgesellschaft der frühen Bundesrepublik entwickelten.

$\mathrm{I}$ N 1969, Helene K. wrote to the Max Planck Institute for Biophysics offering herself for scientific study. She explained that fallout from American nuclear tests in 1955 and her "great sensitivity to radioactivity" had "devastated [her] whole organism," condemning her to years of suffering. She assured the institute that she knew of at least sixty other people "as unlucky and as hopeless as I am." Doctors had been dismissive, Frau K. claimed. "Can you imagine how it felt when a doctor said, 'You don't really believe that [fallout] from

Thanks to Frank Biess, Astrid M. Eckert, Thomas Lekan, Barbara Murdock, Gordon Murdock, and the anonymous readers at Central European History for their suggestions and comments on earlier versions of this article. Thanks also to the Max Planck Institute for the History of Science for funding part of this research. 
... America comes here?"” Further, she suspected that West German scientists and medical professionals with insight into this "special illness" were not sharing their knowledge. ${ }^{1}$ She hoped to help bring to light this health danger, and also the suffering she believed many in the Federal Republic were forced to live with.

Frau K. was not alone in believing that radiation exposure had affected her health. The idea that nuclear radiation shaped human health - for good or ill-was widely accepted in the early twentieth century. ${ }^{2}$ Before the war, radiation exposure in Germany had been associated with select groups: nuclear scientists, some physicians and their patients, and Erzgebirge miners. By the mid-1950s, a decade after the United States had first dropped the atom bomb, the public began to recognize that nearly everyone faced some exposure through medical treatment, nuclear fallout, workplace exposures, consumer goods, or natural sources. Debates about nuclear radiation as a public health issue ranged from a focus on atomic weapons and nuclear energy to consumer safety. By 1970, historical actors ranging from farmers and housewives to physicians, scientists, and bureaucrats had recast nuclear radiation as a public health hazard. In the process, they envisioned a state responsible for overseeing public health issues, from occupational and environmental health to consumer safety.

Narratives about the Federal Republic - especially in the 1950s and 1960s-have emphasized the triumph of order and rationality over the chaos of the Nazi era. As the story goes, new democratic institutions, economic recovery, and the embrace of international organizations such as the North Atlantic Treaty Organization (NATO) and the European Atomic Energy Community (Euratom), all promoted technological and political modernization and long-term stability. ${ }^{3}$ Scholars have recognized that technological dangers such as nuclear war, and outbursts of popular anxiety, such as the anti-nuclear protests of 1957-1958, threatened the march of progress. Yet, historians often present such episodes of unrest and apparent irrationality as the exceptions that ultimately proved the rule, when the Federal Republic triumphed over risk and fear with careful management and technical expertise. ${ }^{4}$ The popular disquiet of the 1950s is supposed to have eased in the 1960s, and the 1970s thus appear as a turning point in which "irrational" opposition emerged to disrupt the political and social stabilization of the preceding two decades. ${ }^{5}$

\footnotetext{
${ }^{1}$ Bundesarchiv (BArch) Koblenz, B 142 No. 1749: 103, letter from Helene K. to Max Planck Institut für Biophysik, Sept. 30, 1969.

${ }^{2}$ Caitlin E. Murdock, "Selling Scientific Authority: Radium Spas, Advertising, and Popular Understandings of Radioactivity in Germany, 1900-1937," German History 35, no. 1 (2017): 21-42.

${ }^{3}$ Edgar Wolfrum, Die geglückte Demokratie. Geschichte der Bundesrepublik von ihren Anfängen bis zur Gegenwart (Stuttgart: Klett-Cotta, 2006), 11-13, 185-86; Heinrich August Winkler, Der lange Weg nach Westen, Vol. 2 (Munich: C. H. Beck, 2000), ix, 142, 160, 181, 222; Konrad Jarausch, After Hitler. Recivilizing Germans, 1945-1995, trans. Brandon Hunziker (New York: Oxford University Press, 2006), 130-55.

${ }^{4}$ Elke Seefried argues that technological progress in the 1950 s-1960s convinced many scientific and political leaders that the future was controllable and thus positive. See Elke Seefried, Zukünfte: Aufstieg und Krise der Zukunftsforschung 1945-1980 (Berlin: de Gruyter, 2015), 1-3, 10.

${ }^{5}$ Michael Geyer, "Cold War Angst: The Case of West German Opposition to Rearmament and Nuclear Weapons," in The Miracle Years: A Cultural History of West Germany, ed. Hanna Schissler (Princeton, NJ: Princeton University Press, 2001), 376; Hans-Ulrich Wehler, Deutsche Gesellschaftsgeschichte. Fünfter Band: Bundesrepublik und DDR 1949-1990 (Munich: C. H. Beck, 2008), 61; Lutz Raphael and Anselm Doering-Manteuffel, Nach dem Boom: Perspektiven auf die Zeitgeschichte seit 1970 (Göttingen: Vandenhoeck \& Ruprecht, 2012), 26.
} 
This article suggests the need for two changes to existing narratives. First, it illustrates that anxieties about uncontrollable technology, ineffective institutions, disingenuous political leaders, and volatile citizens persisted from the 1950s to the 1970s, coexisting with optimism and progress and without truly subsiding in the 1960s. ${ }^{6}$ Indeed, the apparent decline in fears about nuclear weapons and technology often reflected the fact that popular anxieties had shifted focus rather than disappeared. When currents of anxiety and optimism intersected, they shaped public opinion and state policy. These interactions sometimes improved statesociety communication. Equally important, they laid the ground for later popular opposition.

Second, the article urges historians to take both citizens' and officials' fears seriously. Dismissing popular anxiety as irrational or as a passing "spasm" trivializes historical forces that had long-term consequences, and it privileges state narratives over those of ordinary citizens. ${ }^{7}$ Although individual Germans' specific fears about radiation were often unsubstantiated, concern that the Atomic Age posed health risks was in line with growing scientific consensus and shifts in public debate. Further, West German politicians and officials had no monopoly on rationality. Their fears about popular "hysteria" were understandable after Nazism, but their tendency to dismiss any claims of radiation health risk were out of line with scientific knowledge and their own internal discussions. Popular and official fears were the combined products of limited scientific knowledge, a persistent sense of instability, and mutual distrust between the state and its citizens. Such "irrationality" ultimately produced changes in state policy, new public health initiatives, and better understandings of radiation's medical effects. The big environmental and anti-nuclear movements of the 1970s and 1980s were yet to come, but incremental changes in daily life and local practice had already transformed the cultural and policy landscape. ${ }^{8}$

Scholars have tended to treat broad awareness of radiation as a postwar phenomenonexploding into public consciousness in 1945 with the atom bomb and, in the 1950s, promising peaceful postwar technology (e.g., nuclear energy, medicine, and agriculture). ${ }^{9}$ The historiography has emphasized periods of mass protest. In the 1980s and 1990s, studies of early Cold War West German atomic culture explored the Kampf dem Atomtod movement of $1958 .{ }^{10}$ More recently, scholars have shown that anti-nuclear weapons

\footnotetext{
${ }^{6}$ Other work on popular fears in the 1950s and 1960s include Geyer, "Cold War Angst," 376-408; Frank Biess, "Everybody Has a Chance': Nuclear Angst, Civil Defense, and the History of Emotions in Postwar West Germany," German History 27, no. 2 (2009): 215-43; Monica Black, "Miracles in the Shadow of the Economic Miracle: The 'Supernatural '50s' in West Germany," Journal of Modern History 84, no. 4 (2012): 833-60.

${ }^{7}$ E. P. Thompson, "The Moral Economy of the English Crowd in the Eighteenth Century," Past and Present 50 (1971): 76-136.

${ }^{8}$ For the significance of incremental changes, see Jarausch, After Hitler, vii. Michael Geyer also connects the early anti-nuclear protests to later movements. See Geyer, "Cold War Angst," 394.

${ }^{9}$ This was true neither in Europe nor in the United States; see Matthew Lavine, The First Atomic Age: Scientists, Radiation, and the American Public, 1895-1945 (New York: Palgrave, 2013); Murdock, "Selling Scientific Authority"; Maria Rentetzi, "Packaging Radium, Selling Science: Boxes, Bottles and Other Mundane Things in the World of Science," Annals of Science 68, no. 3 (2011): 381-96.

${ }^{10}$ Hans Karl Rupp, Ausserparlamentarische Opposition in der Ära Adenauer (Cologne: Pahl-Rugenstein Verlag, 1970); Mark Cioc, Pax Atomica: The Nuclear Defense Debate in West Germany during the Adenauer Era (New York: Columbia University Press, 1988).
} 
sentiment shaped West German politics into the early 1960s. ${ }^{11}$ Nevertheless, the historiography of public perceptions of radiation generally jumps from the anti-weapons activism of the 1950s to the anti-nuclear power and weapons movements in the 1970s, overlooking other kinds of radioactive risk, and leaving the impression that the issue faded from public consciousness in the 1960s. ${ }^{12}$

In fact, in the 1950s and 1960s, West Germans engaged in public discussions of radiation ranging far beyond fears of nuclear war and American and West German government campaigns promoting "peaceful" nuclear energy, to address environmental contamination, radium therapies, and consumer and occupational safety. The common thread was radiation's significance for public health. Participants ranged from political activists to citizens like Helene K. By the late 1960s, West German politicians could no longer ignore the issue. ${ }^{13}$

Many factors shaped West Germans' views of radiation's health effects. Before World War II, nuclear radiation was touted as a health aid; in the early 1950s, scientists and physicians knew little about its biological effects. Moreover, West German officials downplayed popular fears. The United States and the West German governments celebrated peaceful nuclear technology as offering boundless opportunities. ${ }^{14}$ Responsibility for health policy was scattered across state agencies, making consistent governance difficult. Nevertheless, discussion of nuclear radiation as an environmental hazard and government efforts to eradicate popular radioactive therapies heightened public awareness of radiation's health risks. By defining radioactive risk as a question of public health, these discussions helped pave the way for regional and federal legislation and for later opposition to nuclear power. ${ }^{15}$ Moreover, they illustrate how sea changes in public opinion happen: not necessarily through dramatic events such as Hiroshima or the Kampf dem Atomtod protests, but

\footnotetext{
${ }^{11}$ An early example is Karl Otto, Vom Ostermarsch zur APO: Geschichte der ausserparlamentarischen Opposition in der Bundesrepublik 1960-1970 (Frankfurt/Main: Campus Verlag, 1977). More recent studies include Geyer, "Cold War Angst"; Biess, "Everybody Has a Chance"; Dolores Augustine, "Learning from War: Media Coverage of the Nuclear Age in the Two Germanies," in The Nuclear Age in Popular Media: A Transnational History, 1945-1965, ed. Dick van Lente (New York: Palgrave Macmillan, 2012), 79-116.

${ }^{12}$ Andrew S. Tompkins, Better Active than Radioactive: Anti-Nuclear Protest in 1970s France and West Germany (Oxford: Oxford University Press, 2016), 3; Albrecht Weisker, "Powered by Emotion? Affektive Aspekte in der westdeutschen Kernenergiegeschichte zwischen Technikvertrauen und Apokalypseangst," in Natur und Umweltschutz nach 1945: Konzepte, Konflikte Kompetenzen, ed. Franz-Josef Brüggemeier and Jens Ivo Engels (Frankfurt/Main: Campus Verlag, 2005), 203-21.

${ }^{13}$ Belinda Davis argues that postwar popular politics was not limited to "public" action and that it often produced long-term shifts rather than abrupt change. See Belinda Davis, "What's Left? Popular Political Participation in Postwar Europe," American Historical Review 113, no. 2 (2008): 370, 382.

${ }^{14}$ The United States tracked German public opinion; see National Archives at College Park (NACP), RG306, A1 1005, Box 7, Folder HICOG 215, "German Reactions to the Geneva Conference," 1955; and RG306, A1 1005, Box 7, Folder HICOG 208, "Frankfurt Visitors Appraise the Atomic Energy Exhibit," 1955. Also see Joachim Radkau and Lothar Hahn, Aufstieg und Fall der deutschen Atomwirtschaft (Munich: Oekom, 2013), 53-62.

${ }^{15}$ Radioactive health risk was typically discussed as a question of Volksgesundheit (national health) and not öffentliche Gesundheit (public health), which was understood as encompassing more limited concerns. Scholars now refer to policies to protect and promote the health of a whole population as "public health." For the definition still used by American public health expects, see C.-E. A. Winslow, "The Untilled Fields of Public Health," Science 51, no. 1306 (1920): 30. On the legacy of cultural critique from 1957 to 1958, see Geyer, "Cold War Angst," 394.
} 
through information, activism, and the spreading of opinion across the social and political spectrum. ${ }^{16}$

\section{Public Health in a Radioactive Age}

In 1956, Der Spiegel wrote that Nagasaki and Hiroshima had illustrated that "illness and death from exposure to radioactivity no longer ... threatened only a few scientists." 17 Yet, few Germans treated nuclear radiation as an immediate threat to their lives and health in the decade after $1945 .{ }^{18}$ When fears about radiation grew in the mid-1950s, they were as much about health effects from peacetime environmental contamination-atomic testing fallout or waste from nuclear science and energy - as about atomic war.

Throughout the late 1940s and early 1950s, the West German press reported on atomic bomb devastation in Japan, atomic bomb technology, and American and Soviet atomic testing. ${ }^{19}$ Yet, as West Germans confronted the health legacies of World War II-tuberculosis, sexually transmitted diseases, polio, infant mortality, malnutrition-nuclear war remained a secondary concern. ${ }^{20}$ The American Atoms for Peace project and a nascent West German nuclear power program in 1955 made the mid-1950s seem like a time of "Atomic Euphoria" rather than one of fear. ${ }^{21}$

Still, worries about nuclear radiation were rising in the 1950s, as West Germans realized that radioactive contamination from atomic weapons and technology threatened their health. ${ }^{22}$ Postwar politics and bureaucratic structures meant that those concerns often met with silence, deflection, or even ridicule from the state. During the 1950s, West Germany rejected both Nazi and Communist ideas about "national health" (Volksgesundheit). The government stressed citizens' personal responsibility for health, assigned healthcare to private physicians, and limited regulatory control of physicians. The conservative government of Konrad Adenauer resisted a return to Weimar-era public health practices associated with the Social Democratic Party (SPD) and social welfare initiatives that it thought smacked of "socialism."23 The West German medical establishment focused on acute, not preventive, medicine until the late 1960s, and it was reluctant to intervene on matters of personal choice, such as smoking. ${ }^{24}$

\footnotetext{
${ }^{16}$ For a similar argument about 1970s environmentalists, see Engels, Naturpolitik, 154-60, 205.

17 “Strahlungsschäden: Schrecken des Atom Friedens,” Der Spiegel, June 27, 1956.

${ }^{18}$ For a similar argument, see Ilona Stölken-Fitschen, Atombombe und Geistesgeschichte: Eine Studie der fünfiziger Jahre aus deutscher Sicht (Baden-Baden: Nomos Verlag 1995), 48.

19“300,000 Opfer der Atombombe," Der Kurier, Feb. 4, 1946; "Die Welt in Erwartung des Atomversuchs," Der Kurier, June 28, 1946; “Wasserstoffbombe,” Der Spiegel, April 6, 1950.

${ }^{20}$ Ulrike Lindner, Gesundheitspolitik in der Nachkriegszeit: Grossbritannien und die Bundesrepublik Deutschland im Vergleich (Munich: R. Oldenbourg Verlag, 2004), 17, 62; Rupp, Ausserparlamentarische Opposition, 65; Radkau and Hahn, Aufstieg und Fall, 76.

${ }^{21}$ Radkau and Hahn, Aufstieg und Fall, 53-62; Bernd A. Rusinek, “"Kernenergie, schöner Götterfunken!' Die 'umgekehrte Demontage'. Zur Kontextgeschichte der Atomeuphorie," Kultur und Technik 17 no. 4 (1993): 15-21. Stölken-Fitschen argues that, although atomic euphoria and fear developed in parallel, the press discussed atomic weapons and atomic power separately. See Stölken-Fitschen, Atombombe,189-92.

${ }^{22}$ Stölken-Fitschen, Atombombe, 115-16; Matthias Jung, Öffentlichkeit und Sprachwandel: Zur Geschichte des Diskurses über die Atomenergie (Opladen: Westdeutscher Verlag, 1994), 43-44; Radkau and Hahn, Aufstieg und Fall, 77; Geyer, "Cold War Angst," 398.

${ }^{23}$ Lindner, Gesundheitspolitik, 68.

${ }^{24}$ Donna Harsch, "Translating Smoke Signals: West German Medicine and Tobacco Research, 1950-1970," Social History of Medicine 28, no. 2 (2014): 370.
} 
West German citizens embraced state withdrawal from health initiatives such as mass health screenings and immunizations, and came to consider health an individual right integral to postwar democracy. But they did not, as scholars seem to assume, abandon public health as a collective commitment. ${ }^{25}$ Citizens demanded that the government ensure safe environments, workplaces, food and water supplies, and consumer goods, as well as that it combat contagious disease. They questioned the Federal Republic's ability to provide security, but believed that government intervention should mitigate large-scale risks - such as radioactive fallout - that individuals could not control. ${ }^{26}$ By the early 1960s, the state accepted this role, to some degree. As Minister for Atomic Energy Dr. Siegfried Balke explained in 1962, the government saw protection from radioactive fallout as fundamentally different from interference in doctors' clinical use of radiation. ${ }^{27}$

Nuclear radiation had been celebrated as revolutionary for both allopathic medicine and alternative therapies since the early twentieth century. In the 1930s, this positive reputation faltered but did not disappear, even as scientists, miners, and others with chronic exposure developed cancers and other illnesses. ${ }^{28} \mathrm{New}$ atomic technology broadened concerns after World War II. Early stories about the bombing of Hiroshima and Nagasaki in 1945 and about American atomic tests in the Bikini Atoll in 1946 and 1954 proved that radioactive fallout could cover vast distances and be deadly to people who encountered high-level radiation. ${ }^{29}$ By the mid-1950s, West Germans opened their newspapers daily to read that fallout from American and Soviet tests was polluting air, drinking water, and foods in Bavarian farmyards, as well as in the Bikini Atoll. ${ }^{30}$ American and Soviet nuclear testing in 1956-1958 and 1961-1962 intensified these reports and the fears they provoked.

Worries about radiation contamination emerged alongside warnings that postwar industrial pollution threatened public health, drinking water, and other critical resources. ${ }^{31}$

\footnotetext{
${ }^{25}$ Lindner, Gesundheitspolitik, 37, 63; Winfried Süss, "Gesundheitspolitik," in Drei Wege deutscher Sozialstaatlichkeit. NS-Diktatur, Bundesrepublik und DDR im Vergleich, ed. Hans Günter Hockerts (Munich: Oldenbourg, 1998), 61, 89-94; Thomas Gerst, "Neuaufbau und Konsolidierung: Ärztliche Selbstverwaltung und Interessenvertretung in den drei Westzonen und der Bundesrepublik Deutschland 1945-1995," in Geschichte der deutschen Ärzteschaft, ed. Robert Jütte (Cologne: Deutscher Ärzte-Verlag, 1997), 196; Jens Ivo Engels, Naturpolitik in der Bundesrepublik: Ideenwelt und politische Verhaltensstile in Naturschutz und Umweltbewegung 1950-1980 (Paderborn: Schöningh, 2006), 134.

${ }^{26}$ Geyer, "Cold War Angst," 385, 397. This embrace of state responsibility fits Ulrich Beck's thesis that atomic and other global threats transformed understandings of risk from individual to collective in the 1970s-1980s. My evidence shows that it was already underway in the 1950s-1960s. See Ulrich Beck, Risk Society: Towards a New Modernity, trans. Mark Ritter (London: Sage Publications, 1986), 13, 21.

${ }^{27}$ BA Koblenz, B 142 No. 1716: 128, stenographic minutes of the German Bundestag, Jan. 24, 1962.

${ }^{28}$ Murdock, "Selling Scientific Authority."

29 “Tagebuch eines amerikanischen Arztes über Bikini," Die Zeit, Jan. 20, 1949. Occasional stories still suggested health benefits; see, e.g., "Atombombe also Heilmittel," Der Kurier (Berlin), April 3, 1946; Stölken-Fitschen, Atombombe, 91-99.

30 “Die Luft über Europa wurde radioaktiver," Passauer Neue Presse, Dec. 1, 1955; Raymond Dominick, The Environmental Movement in Germany: Prophets and Pioneers, 1871-1971 (Bloomington: Indiana University Press, 1992), 187; Stölken-Fitschen, Atombombe, 101, 117-18.

${ }^{31}$ Historians used to assume that environmental concerns emerged in the 1970 s, but recent literature shows that there was already some debate in the 1950s and 1960s; see Monika Bergmeier, Umweltgeschichte der Boomjahre: Das Beispiel Bayern, 1949-1973 (Münster: Waxmann, 2002); Dominick, The Environmental Movement, 182-214; Engels, Naturpolitik. On threats to water, see Thomas Lekan, "Saving the Rhine: Water, Ecology, and Heimat in Post-Word War II Germany," in Rivers in History: Perspectives on Waterways in Europe and North America, ed. Christof Mauch and Thomas Zeller (Pittsburgh, PA: University of Pittsburgh Press, 2008). On awareness of air pollution in the 1950s, see Frank
} 
Postwar pollution concerns shifted away from earlier nature conservation to more environmental focus on industrial effluents and chemical pollution. Radiation contaminationinvisible, pervasive, potentially deadly — was a potent example of the dangers of postwar technology. ${ }^{32}$ Critics pointed to the dangers of pollution to human health, rather than to an ecology in which humans were only one factor. ${ }^{33}$ The West German government began monitoring environmental radiation levels from fallout in 1955 to assess potential risks posed by nuclear war and to demonstrate its attention to public health safety. Its reports showed a sharp increase in environmental radiation after US and Soviet nuclear tests in the mid-1950s, and they expanded testing through the end of the decade. ${ }^{34}$

Data alone were not enough to evaluate radiation risk or calm public fears. Assessments of radioactive fallout's implications varied widely. In the 1950s, reports of heightened atmospheric radiation after atomic tests often contained official reassurances. ${ }^{35}$ In 1953, the Hamburger Abendblatt reported that the UN Atomic Energy Commission (UNAEC) had dismissed concerns, claiming that atmospheric radiation levels were hardly more than those of the luminous watches that contained radium paint but were still considered harmless. ${ }^{36}$ Yet, from the mid-1950s on, scientists, physicians, and journalists warned the public repeatedly that rising radiation levels posed immediate danger. ${ }^{37}$ One radiation researcher responded to the UNAEC's argument in this way: "Sure, radiation from luminous watches is minimal, but I find it unsettling when the whole street is paved with such watches." 38 In 1955, University of Munich physicist Dr. Jakob Kranz told Bavarian SPD officials, "radioactive dust released into the atmosphere by atomic explosions is reaching levels in Germany that can no longer be described as safe." 39 "Humanity is threatened," wrote journalist and Christian Social Union (CSU) member August Ramminger in 1955: Strontium 90 from Soviet atomic tests was contaminating German soil and entering the food chain and human bodies, he explained. "No one knows what dose is dangerous ... We know much more about atomic technology than about the dangers radioactive air poses for humans ...

Uekötter, The Age of Smoke: Environmental Policy in Germany and the United States, 1880-1970 (Pittsburgh, PA: University of Pittsburgh Press, 2009), 132-36.

${ }^{32}$ Lekan, "Saving the Rhine," 112, 116, 118. On industrial pollution as a national problem, see FranzJosef Brüggemeier, Schranken der Natur: Umwelt, Gesellschaft, Experimente 1750 bis heute (Essen: Klartext Verlag, 2014), 242.

${ }^{33}$ For a similar argument about 1950 s attitudes toward water pollution, see Thomas Schlemmer and Hans Woller, eds., Bayern im Bund: Die Erschließung des Landes, 1949 bis 1973 (Munich: R. Oldenbourg Verlag, 2001), 20.

${ }^{34}$ Johannes Abele, "Safety Clicks: The Geiger-Müller Tube and Radiation Protection in Germany, 1928-1960," in Manifesting Medicine: Bodies and Machines, ed. Robert Bud, Bernard Finn, and Helmuth Trischler (London: NMSI Trading Ltd, 2004), 90, 92. The University of Freiberg's Physics Institute found heightened radiation in 1953, i.e., before the government did. See Stölken-Fitschen, Atombombe, 117; BArch Koblenz, B 136 No. 2046, 60-61, departmental meeting minutes, Bundesministerium für Atomkernenergie (BM Atom), planned response to SPD parliamentary question, Dec. 12, 1960. The 1950s also saw calls for general monitoring of pollution; see Lekan, "Saving the Rhine," 115; Uekötter, The Age of Smoke, 139.

35 “Atomschwäden über uns," Hamburger Abendblatt, Oct. 26, 1955; “Atom-Strahlung über Deutschland ist stärker geworden," Hamburger Abendblatt, Nov. 28, 1955.

36 “Heisse Wolken über Europa," Hamburger Abendblatt, June 11, 1953.

${ }^{37}$ Abele, "Safety Clicks," 90; "Warnung vor radioaktiven Strahlen," Passauer Neue Presse, July 5, 1956.

38 "Heisse Wolken über Europa," Hamburger Abendblatt, June 11, 1953.

39 “Radioaktiver Staub über Deutschland,” Passauer Neue Presse, Nov. 7, 1955. 
By the time we have enough experience, it will be too late for many." 40 These warnings indicated that fallout posed new risks in addition to those of familiar exposures from watches or medical treatment, and more immediate than a hypothetical war. Fallout was ubiquitous, cumulative, and hard to measure. That no one knew how to assess the danger was alarming. There was no accepted definition of a toxic dose and no standard way to measure pollutants' atmospheric travel. Some press reports suggested that official reassurances were disingenuous. In 1955, newspapers claimed that milk was contaminated, and that West Germany secretly tested fish for radiation before they were sold, suggesting that the government knew the dangers were greater than officials would admit. ${ }^{41}$

The West German public responded to reports of fallout contamination with alarm. In 1956, public interest in US and Soviet atomic tests prompted the Hamburger Abendblatt to monitor the air for radiation and to publish daily readings alongside the weather report. ${ }^{42}$ Stories of suspected radiation contamination or illness flooded newspapers and government offices. In one poll, 59 to 68 percent of respondents attributed the summer's cold, wet weather to radiation contamination. ${ }^{43}$ The Austrian and German press reported that patients in Salzburg had complained of headaches and fainting spells at the same time that meteorologists had detected atmospheric radioactivity from fallout — cases the press declared "atomic illnesses." 44 The Münchner Merkur asserted: "Every ... new atomic test unsettles the public, and today, whenever someone has a headache, the sniffles, or even the flu, they blame radiation." 45 An alarmed employee of the Atomic Ministry similarly reported that rain had turned her wash blue, prompting two ministry officials and a physicist to examine her laundry with Geiger counters. ${ }^{46}$ The Passauer Neue Presse suggested that, if atomic testing continued, citizens might need radiation self-protection: "Perhaps a Geiger counter will stand on every dining table next to the salt and pepper so that the modern person can check his food for atomic traces ... Perhaps we will use lead umbrellas." 47 Speculation aside, some citizens acted on perceived radiation threats. As early as 1954, two brothers in Bad Ems developed a "biometer" the size of a wristwatch to allow citizens to detect radiation. ${ }^{48}$ And, in 1957, Black Forest farmers who noticed that their cows refused to eat their hay concluded that radioactive rain had contaminated the fodder. The farmers stopped drinking milk from their own cows. ${ }^{49}$

Reports of fallout in West Germany expanded the focus of popular radiation fears well beyond the threat of atomic tests. As journalist Leo Nitschmann wrote in Die Zeit in

\footnotetext{
${ }^{40}$ August Ramminger, "Die Menschheit ist Bedroht,” Passauer Neue Presse, Dec. 1, 1955.

41 "Bisher streng geheim," Hamburger Abendblatt, Oct. 7, 1955; Abele, "Safety Clicks," 90.

42 “Der Heisse Regen," Der Spiegel, July 18, 1956; “Atomregen unter Kontrolle," Hamburger Abendblatt, Sept. 1, 1956.

${ }^{43}$ Stölken-Fitschen, Atombombe, 123.

44 “"Mysteriöse Atomkrankheit' in Salzburg,” Passauer Neue Presse, June 18, 1956.

${ }^{45}$ Bayerisches Hauptstaatsarchiv (BayHStA), Staatskanzelei (StK) 21077, "Wächter unseres Trinkwassers," Münchner Merkur, Oct. 11, 1957.

46"Der Heisse Regen," Der Spiegel, July 18, 1956. There were similar reports in Celle. See "DamenWäsche war nicht radioaktiv," General-Anzeiger (Bonn), July 7, 1956, cited in Stölken-Fitschen, Atombombe, 305.

47 “Münchner Brief," Passauer Neue Presse, June 23, 1956.

48 “Biometer, das Gerät des Atomzeitalters," Passauer Neue Presse, Dec. 24, 1954. Multiple companies were developing Volks-Geiger counters by the early 1960s. See Abele, "Safety Clicks," 98.

49 “Kuhe fressen 'radioaktives' Heu nicht,” Passauer Neue Presse, Feb. 6, 1957.
} 
1956: "The atomic age has begun. We must use all scientific means to defuse its dangers." 50 In 1958, he quoted a German physicist who went even further, suggesting, "We should no longer speak of an 'Atomic Age' but rather of a 'Radioactive Age' ... Our environment is rapidly becoming radioactive... and we haven't even begun to use atomic energy." 51 Scholars have long suggested that, in the late 1950s and the 1960s, West Germans considered atomic weapons and nuclear fallout threatening, but treated atomic energy and technology as benign and beneficial. This bifurcated view was common. ${ }^{52}$ Yet, as the article in Die Zeit demonstrated, media and popular opinion quickly connected environmental health dangers from fallout to other radiation risks, including the planned development of nuclear energy and technology. ${ }^{53}$ A 1955 survey showed that two-thirds of adults associated atomic energy with bombs. ${ }^{54}$ Anti-nuclear activists such as Bodo Manstein warned that waste from nuclear energy production could be as dangerous as atomic weapons. ${ }^{55}$ As early as 1954, Joseph Baumgartner of the conservative Bayernpartei asked the Bavarian government how they would protect groundwater from radioactive wastewater from planned nuclear reactors. ${ }^{56}$ In 1955, Munich's beer brewers sought reassurances that atomic energy would not contaminate their water and hops. ${ }^{57}$ And, in 1956, at the height of the "atomic psychosis" about radioactive fallout, the Munich City Council held a meeting to discuss radiation's health risks in response to popular alarm about plans to make the region a center for atomic research and energy. ${ }^{58}$ Even natural environmental radiation-once touted as curative by spas - sometimes met with suspicion. In 1959, for example, a popular healer from Upper Franconia was jailed for selling farmers creations of steel wire and stones that, he claimed, would protect them from "malignant earth radiation." 59

West German officials distrusted popular sentiment and often dismissed such fears as irrational and ill-informed. ${ }^{60}$ As the Bavarian Ministry of the Interior's Center for Radiation Monitoring wrote in 1957, "arguments about the current danger are made with more fervor than expertise." 61 In 1956, a Bavarian Undersecretary of Health pooh-poohed reports of migraine headaches as "atomic psychosis" and "speculation," complaining, "Bavarians are calling everything ... an atomic headache."62 The Passauer Neue Presse also

\footnotetext{
${ }^{50}$ Leo Nitschmann, "Sind wir schon durch Atomstrahlen bedroht?," Die Zeit, July 26, 1956.

${ }^{51}$ Leo Nitschmann, "Strahlen drohen," Die Zeit, Nov. 13, 1958.

${ }^{52}$ For positive formulations in the 1950s, see Jung, Öffentlichkeit, 44-45; Radkau and Hahn, Aufstieg und Fall, 75.

${ }^{53}$ Also see Stephan Deutinger, "Eine 'Lebensfrage für die bayerische Industrie'. Energiepolitik und regionale Energieversorgung 1945 bis 1980," in Schlemmer and Woller, Bayern im Bund, 60.

${ }^{54}$ Brüggemeier, Schranken der Natur, 229; Radkau and Hahn, Aufstieg und Fall, 68.

${ }^{55}$ Bodo Manstein, Atom bedroht die Welt (Detmold: Kampf gegen Atomschäden, 1957), 13-14.

${ }^{56}$ Deutinger, "Ein 'Lebensfrage für die bayerische Industrie,", 57.

57 “Atomkraft und Kraftbier,” Die Zeit, Oct. 27, 1955.

58 “Münchner Brief," Passauer Neue Presse, June 23, 1956. On atomic research centers as health threats, see Josef Müller-Marein, "Explosion in Bonn,” Die Zeit, July 4, 1957.

59،"Alter Draht als 'Heilmittel' gegen Erdstrahlen,” Passauer Neue Presse, Dec. 15, 1959.

${ }^{60}$ Frank Biess and Monica Black argue that politicians in the 1950s emphasized stability and conformity, and that they glossed over popular fears to quash "mass hysteria" and Nazi-era dynamics. See Biess, "Everybody Has a Chance," 219-20; Black, "Miracles in the Shadow of the Economic Miracle," 835, 853-54.

${ }^{61}$ BayHStA, StK 21077, “Bericht der Zentralstelle zur Überwachung der Radioaktivität,” Dec. 11, 1957.

62 "Bisher keine radioaktiven Schäden," Passauer Neue Presse, June 26, 1956; "Der Heisse Regen," Der Spiegel, July 18, 1956.
} 
suggested that reports of atomic headaches in Salzburg had sparked "atomic psychosis" in Munich, where "everyone now imagines he is suffering from a headache and dizziness ... griping over their beers, 'It's because of the damned atomic nonsense!" 63 During the 1950s, some politicians and bureaucrats asserted that media and public discussion of radiation had whipped up "atomic fear" and "neurosis," and they urged that official efforts to address radiation health risks be kept quiet to avoid public unrest. ${ }^{64}$ Government attempts to contain "atomic psychosis" reflected early Cold War military strategies to minimize popular panic in the event of a nuclear war. ${ }^{65}$ Critics even suggested that the Soviets were promoting "atomic psychosis" to undermine the Federal Republic and the West-warnings that continued into the early 1960s. ${ }^{66}$

The state's failure to communicate radiation's risks throughout much of the 1950s reflected a fragmented regulatory landscape, as well as officials' fears of public panic. The early Federal Republic had limited legal means to monitor or control radiation exposure and its health effects. It had inherited a few Weimar- and Nazi-era laws about occupational exposure in mining and medicine. But there was no general regulation of occupational exposure, environmental chemical pollution legislation did not yet exist, and pharmaceutical laws did not cover radioactive materials. Most health policy officially fell to the states (Länder), not federal authorities. ${ }^{67}$ Yet, state governments had neither the expertise nor legal basis to regulate radiation exposure. ${ }^{68}$ Further, public health administration was split among the Atomic Ministry, Labor Ministry, Interior Ministry, and other agencies at both federal and state levels, hampering the development and implementation of coherent policy. ${ }^{69}$

By the late 1950s, the regulatory landscape had changed dramatically, at least on paper. In 1956, the federal government announced new international norms, and plans to develop nuclear power and medicine made radiation health-protection legislation necessary. ${ }^{70}$ Participation in the Euratom Treaty, the Organization for European Economic Cooperation (OEEC), and the International Labor Organization (ILO) committed West Germany to international radiation protection standards and it forced the government to engage more openly with radiation health risks. ${ }^{71}$ Domestic voices such as the German Green Cross health advocacy group and the German Congress of Physicians also declared

\footnotetext{
63“"Münchner Brief," Passauer Neue Presse, June 23, 1956.

${ }^{64}$ BayHStA, Ministerium für Arbeit und Sozialfürsorge (MArb.) 2559, letter from Dr. Nathusius (Verband der Heimkehrer) to Bayerischer Staatsminister für Arbeit, Dec. 17, 1956; BayHStA, MArb. 2559, letter from Dr. Koetzing, Bundesministerium für Arbeit und Sozialordnung (BM Arbeit u. Sozial), to Dr. Girscheck, Dec. 20, 1957.

${ }^{65}$ Frank Biess, "The Concept of Panic: Military Psychiatry and Emotional Preparation for Nuclear War in Postwar West Germany," in Science and Emotions after 1945: A Transatlantic Perspective, ed. Frank Biess and Daniel M. Gross (Chicago, IL: University of Chicago Press, 2014), 182.

66،"Vorbereitung für Atom-Volksbefragung," Passauer Neue Presse, April 12, 1958; BArch Koblenz, B 142 No. 1716, 124, stenographic minutes of the German Bundestag, Jan. 24, 1962.

${ }^{67}$ Lindner, Gesundheitspolitik, 39-40.

${ }^{68}$ Josef Müller-Marein, "Explosion in Bonn," Die Zeit, July 4, 1957.

${ }^{69}$ Lindner, Gesundheitspolitik, 40-41.

${ }^{70}$ BArch Koblenz, B 136 No. 2046: 45-50, Ausführung der Regierung an das Parlament zum Strahlenschutzgesetz, 1956.

${ }^{71}$ The Euratom treaty went into effect in 1958. See BArch Koblenz, B 136 No. 2046: 121, BM Atom Minutes, May 5, 1960. OEEC rules went into effect in 1959. See BArch Koblenz, B 136 No. 5374, Bundesrat Drucksache 57/61. The ILO required occupational protection by December 1961. See BArch Koblenz, B 106 No. 27948, letter from Minister of Family and Youth to Bundesrat President, Dec. 22, 1961.
} 
that fallout and nuclear power had made radiation protection an urgent public health issue. ${ }^{72}$ In 1958, the SPD parliamentary caucus asked the federal and state governments to address radiation contamination, train radiation physicians and biologists, and fund research on radiation's biological effects. ${ }^{73}$ Finally, a 1959 constitutional amendment made the federal government responsible for protecting citizens from ionizing radiation. ${ }^{74}$

The first federal radiation protection law-passed in June 1960 - set standards for handling radioactive substances, required permits for possession and trade in many radioactive materials, established occupational dose limits, and created guidelines for environmental protection, warning labels for radioactive materials, and standards for radioactive waste disposal. ${ }^{75}$ The federal Ministries of the Interior, Agriculture and Forestry, Labor and Social Welfare, Transportation, and Atomic Energy and Water Resources expanded monitoring of occupational exposure and radiation in air, soil, and water. ${ }^{76}$ They also enlisted the help of scientific institutes already monitoring radiation. ${ }^{77}$ The German states were to track radiation in waterways, drinking water, and fresh foods, including produce, milk products, and fish. ${ }^{78}$ In November 1961, West Germany finally created a single federal Health Ministry, bringing many health issues under one roof. ${ }^{79}$ Still, policies related to radiation and public health remained divided among multiple ministries and agencies.

West German politicians hoped that new regulations, and a slow-down in international nuclear testing, would ease "atomic psychosis." But, in the fall of 1961, further Soviet nuclear tests prompted citizens' fears anew. Headlines in the press screamed: "Death rains from the clouds" and "Atomic plumes over Germany." 80 That November, the SPD asked the government to explain (and defend) its fallout protection measures. In a Bundestag debate in January 1962, Dr. Elinor Hubert of the SPD called increased radiation "one of the most serious environmental problems threatening human health." She suggested that the government's response-releasing environmental data few citizens could interpret - was inadequate. ${ }^{81}$ The Christian Democratic Union (CDU) government insisted that radiation spikes would probably stay within a safe range, but politicians across the political spectrum nevertheless agreed that the Soviet tests posed a public health risk. This consensus translated into policy addressing food and water safety, among other measures.

The SPD's inquiry emphasized environmental pathways through which radiation could harm human bodies. The 1962 parliamentary debate shifted attention from air pollution alone to precipitation and soil pollution as vectors for radiation contamination of food and water. Seen this way, nuclear fallout threatened citizens' basic needs: clean drinking water, bread, and milk for children. This echoed a broader consensus that environmental degradation undermined West German well-being, and ideas arising from conservationist and

\footnotetext{
${ }^{72}$ BArch Koblenz, B 136 No. 2046: 24, 36, Green Cross letter, Nov. 15, 1956, and Congress of Physicians press release, June 1957.

${ }^{73}$ BArch Koblenz, B 136 No. 2046: 53, Antrag-SPD Bundestag Fraktion, July 1, 1958.

${ }^{74}$ BArch Koblenz, B 136 No. 2046: 121, BM Atom Minutes, May 5, 1960; Deutsches Grundgesetz, Artikel $74 \mathrm{Nr} 11 \mathrm{a}$.

75 "Erste Strahlenschutzverordnung" (June 24, 1960), in Bundesgesetzblatt no. 31 (June 30, 1960): 430-51.

${ }^{76}$ BArch Koblenz, B 136 No. 2046: 81-84, BM Atom report to Bundestag President, Dec. 22, 1960.

${ }^{77}$ BArch Koblenz, B 136 No. 2046: 121, 131, BM Atom minutes, May 5, 1960.

${ }^{78}$ BArch Koblenz, B 136 No. 2046: 60-64, report of departmental meeting, BM Atom, Dec. 12, 1960.

${ }^{79}$ Lindner, Gesundheitspolitik, 42-43.

80 “Atomschwaden über Deutschland,” Der Spiegel, Nov. 22, 1961.

${ }^{81}$ BArch Koblenz, B142 No. 1716: 122, stenographic minutes of the German Bundestag, Jan. 24, 1962.
} 
government initiatives since the 1950s crystalized in the Green Charter of Mainau in 1961. This conservationist document held that good health and a clean environment were human rights, and it helped set the stage for the West German environmental movement in the 1970s. ${ }^{82}$

The Ministry of Atomic Energy and Water Resources nevertheless insisted that contamination levels were too low to cause health problems. But Social Democrats and other critics argued that, because radiation exposure was cumulative, atomic testing ongoing, and health effects slow to emerge, downplaying the risk was dangerous. ${ }^{83}$ Radiation exposure could not only increase contemporary rates of cancer and other illnesses, but also cause genetic problems in future generations. ${ }^{84}$

Concerns about radiation contamination of drinking water were part of a larger postwar environmental health debate in the Federal Republic. In the 1950s, environmentalists and the press argued that West Germany faced an unprecedented potable water crisis caused by modernization, insufficient infrastructure, industrial pollution, and radiation contamination. ${ }^{85}$ They suggested that West Germany's focus on industrial and technological growth was undermining basic public needs. ${ }^{86}$ In response, the federal government began extending centralized water systems to rural areas in 1956, part of a "Green Plan" to improve West Germany's agricultural sector. ${ }^{87}$ Fears that Soviet nuclear tests could contaminate drinking water forced the Adenauer administration to pursue the policy more aggressively. Testing showed that radioactive fallout flushed out of waterways without contaminating groundwater. But radioactive rain concentrated via evaporation in cisterns, which provided drinking water for many rural communities-especially in Schleswig-Holstein, Lower Saxony, and Bavaria. ${ }^{88}$ The Green Plan shifted two hundred thousand people off rainwater cisterns by 1961. ${ }^{89}$ An estimated forty-five thousand cisterns remained, providing drinking water for over three hundred thousand people. ${ }^{90}$ The government planned to connect these people to central water supplies within two years, worked with industry to develop filters for cisterns, and prepared to truck water to rural areas if radiation levels in the cisterns rose. ${ }^{91}$

The SPD inquiry stressed minimizing radiation in the food chain. West Germans first realized in 1954 that nuclear fallout could contaminate food, based on reports about US atomic testing in the Pacific. ${ }^{92}$ By the late 1950s, radiation fallout was contaminating West German

\footnotetext{
${ }^{82}$ Sandra Chaney, Nature of the Miracle Years: Conservation in West Germany, 1945-1975 (New York: Berghahn, 2008), 133-34; Engels, Naturpolitik, 131-34.

${ }^{83}$ BArch Koblenz, B142 No. 1716: 8, memo by Dr. Clodius, BM Atom, Dec. 1, 1961; Bulletin des Presseund Informationsamtes der Bundesregierung (Jan. 26, 1962): 151.

${ }^{84}$ BArch Koblenz, B142 No. 1716: 122, stenographic minutes of the German Bundestag, Jan. 24, 1962. Anti-nuclear critics had stressed this since the mid-1950s. See Stölken-Fitschen, Atombombe, 127-31.

${ }^{85}$ Earlier concerns about water contamination focused on particular industries and locales. See Jürgen Büschenfeld, Flüsse und Kloaken: Umweltfragen im Zeitalter der Industrialisierung (1870-1918) (Stuttgart: Klett-Cotta, 1997), 289-399.

${ }^{86}$ Dominick, The Environmental Movement, 139-43; Lekan, "Saving the Rhine," 118

${ }^{87}$ BArch Koblenz, B 142 No. 1716: 17, letter from BM für Ernäherung, Landwirtschaft u. Forsten (BM ELF) to Bundesminister für Gesundheitswesen (BM Gesundheit), Dec. 11, 1961.

${ }^{88}$ BArch Koblenz, B 142 No. 1716: 6, memo from Dr. Clodius, BM Atom, Dec. 1, 1961.

${ }^{89}$ BArch Koblenz, B 142 No. 1716: 17, letter from BM ELF to BM Gesundheit, Dec. 11, 1961.

${ }^{90}$ BArch Koblenz, B 142 No. 1716: 6, memo fom Dr. Clodius, BM Atom, Dec. 1, 1961.

${ }^{91}$ BArch Koblenz, B 142 No. 1716: 24, draft reply to SPD from Ministry of Finance, BM Atom, and BM ELF, Dec. 27, 1961.

${ }^{92}$ Stölken-Fitschen, Atombombe, 95-99.
} 
soil and water and then being absorbed by plants, making its way into grain and fresh produce. When livestock ate contaminated grass or fodder, radioactive materials, Iodine 131, and Strontium 90 turned up in their milk and meat. The government assured parliament that it was monitoring radiation in key foodstuffs and that it had begun stockpiling dried and condensed milk in case fresh supplies showed dangerous radiation levels. ${ }^{93}$ The Agriculture Ministry said it had grain reserves that would last a few months; besides, contaminated grain could be diluted with clean supplies, or processed to remove the worst contaminants. ${ }^{94}$

Steps to protect the public from potential fallout reflected policies initiated in the late 1950s, but many were responses to the SPD inquiry, the radiation protection legislation of 1960, and public discussion of fallout risk. ${ }^{95}$ New measures and parliamentary debate reflected shifting attitudes toward "atomic psychosis" and environmental radiation as a public health risk. Although many politicians, especially on the political right, still thought popular fears overblown, most agreed that fallout might be dangerous. By the early 1960s, many politicians, officials, and citizen groups argued that providing more information about radiation monitoring and risk would calm public fears. ${ }^{96}$ As Minister of Health Elisabeth Schwarzhaupt of the CDU told the Bundestag in 1962, "Dangers appear larger in fog ... accurate information can be calming." 97

Disagreement persisted about what was "accurate." The SPD asserted that fallout could cause long-term pollution or genetic damage; the conservative majority considered Soviet tests a real but short-term issue. ${ }^{98}$ Atomic Energy Minister Dr. Siegfried Balke argued that such passing risk did not warrant long-term barriers to nuclear power or medicine. Overwrought warnings could do more harm than good: "Has radioactivity become so dangerous that state governments must interfere in citizens' daily lives?"99

Government efforts to limit public health damage from fallout did not mean abandoning the idea that citizens should protect their own health. The Adenauer administration suggested that, in periods of heightened radiation, farmers should keep dairy cows off pasture, and that everyone should wash fresh produce and use frozen vegetables and dried milk. ${ }^{100}$

${ }^{93}$ BArch Koblenz, B 142 No. 1716: 31, draft response to SPD Anfrage, 1961; BArch Koblenz, B 142 No. 1716: 21, Anlage to BM ELF memo, Dec. 21, 1961; BArch Koblenz, B 136 No. 5374, BM Atom report on environmental radiation, April 24, 1962.

${ }^{94}$ BArch Koblenz, B 142 No. 1716: 22, Anlage to BM ELF memo, Dec. 21, 1961.

${ }^{95}$ BA Koblenz, B 136 No. 5374: BM Atom memo to Landesbehörden für Strahlenschutz, Gesundheitswesen, Wasserwirtschaft u. ELF, April 24, 1962; BA Koblenz, B 142 No. 1716: 64, memo from Bundesministerium des Innern (MInn) to Bundesministerium der Finanzen, Jan. 15, 1962.

${ }^{96}$ BayHStA, MArb. 2559, letter from Dr. Nathusius (Verband der Heimkehrer) to Bayrischer Staatsminister für Arbeit, Dec. 17, 1956; BayHStA, MArb. 2559, letter from Dr. Koetzing (BM Arbeit u. Sozial) to Dr. Girscheck, Dec. 20, 1957; BArch Koblenz, B 142 No. 1716, 123-24, stenographic minutes of the German Bundestag, Jan. 24, 1962. This coincided with West Germans abandoning their perception of popular fear as something that was pathological. See Biess "Everybody Has a Chance," 240.

${ }^{97}$ BArch Koblenz, B 142 No. 1716: 129, stenographic minutes of the German Bundestag, Jan. 24, 1962.

${ }^{98}$ BArch Koblenz, B 142 No. 1716: 122-29, stenographic minutes of the German Bundestag, Jan. 24, 1962; BA Koblenz, B 136 No. 5374, Referat for Ministerialdirektor Dr. Viaolon (Bundeskanzleramt), Oct. 23, 1961.

${ }^{99}$ BArch Koblenz, B 142 No. 1716: 128-29, stenographic minutes of the German Bundestag, Jan. 24, 1962.

${ }^{100}$ BArch Koblenz, B 142 No. 1716: 21, Anlage to BM ELF memo, Dec. 21, 1961; Theo Löbsack, "Schutz vor strahlendem Regen," Die Zeit, April 20, 1962. 
The message of citizen self-reliance probably bolstered sales of the so-called Volksgeigerzähler, devices consumers could use to test for radiation. But it also met with popular and political resistance. Authorities claimed that fallout was not a major concern, yet conceded that it might confine people to their homes for days. ${ }^{101}$ The SPD argued that the administration still downplayed the risk and failed to give the public information it needed. ${ }^{102}$ In parliamentary debates in January 1962, SPD Bundestag health spokesperson (and physician) Elinor Hubert insisted, "The population needs to know ... that the federal government is taking measures to protect it." 103

In 1963, the West German government hailed a US, British, and Soviet treaty banning all but underground nuclear testing as an end to radioactive fallout. Die Zeit asserted that ending atomic testing was the only way to halt the rising environmental radiation threatening human health. ${ }^{104}$ Popular radiation fears receded as environmental contamination and media coverage fell, but they did not vanish. During the 1961-1962 fallout scare, the government argued that fallout was a unique risk, since it originated outside the Federal Republic's territory and control, and that German government oversight guaranteed safe atomic energy and other domestic uses of radiation. ${ }^{105}$ The public had often rejected such distinctions in the late 1950s, when fallout danger was high. But, by the late 1960s, many citizens accepted the idea that, with oversight, nuclear energy was safe. ${ }^{106}$ Yet, skeptics remained. Stories about food contaminated by environmental radiation surfaced repeatedly. ${ }^{107}$ In the mid-1960s, communities challenged projected nuclear plants and radioactive waste collection sites, citing environmental public health to demand that projects be cancelled or relocated. ${ }^{108}$ In 1967, a poster protesting a proposed nuclear power plant in Würgassen proclaimed: "Atoms from Würgassen Create Infirmity, Crippling, and Death." ${ }^{109}$ Media coverage of protests used similar terms. For example, the Neue Westfälische Zeitung quoted physicist and SPD parliamentarian Karl Bechert: "Life near an atomic power plant is as dangerous as living by a powder factory. Invisible radioactive clouds from an accident can endanger the neighbors' lives." 110 By the late 1960s, many West Germans were convinced that environmental radiation already threatened their health. Moreover, the realization that radioactive health aids were endangering personal and public health only bolstered the warnings discussed earlier, as well as the complaints connecting illnesses, real or imagined, to radiation exposure.

\footnotetext{
${ }^{101}$ Löbsack, "Schutz vor strahlendem Regen." Frank Biess finds that government assurances in 1961 that citizens could protect themselves in a nuclear war reinforced popular beliefs that the state offered them insufficient protection. See Biess, "Everybody Has a Chance," 234-36.

${ }^{102}$ BArch Koblenz, B 142 No. 1716: 125-28, stenographic minutes of the German Bundestag, Jan. 24, 1962.

${ }^{103}$ Ibid., 122.

${ }^{104}$ August Ramminger, "Schluss mit der radioaktiven Verseuchung," Die Zeit, Aug. 23, 1963.

${ }^{105}$ BArch Koblenz, B 142 No. 1716: 128, stenographic minutes of the German Bundestag, Jan. $24,1962$.

${ }^{106}$ Dominick, The Environmental Movement, 166.

107 “Radioaktiv verseuchtes Fleisch,” Passauer Neue Presse, Sept. 21, 1965.

${ }^{108}$ Dominick, The Environmental Movement, 167; "Wird das Grundwasser radioaktiv verseucht?," Hamburger Abendblatt, July 22, 1964; BArch Koblenz, B 106 No. 27948, answers by Bundesregierung to Representative Dröscher (SPD), Oct. 19, 1967.

${ }^{109}$ Dominick, The Environmental Movement, 168.

${ }^{110}$ Max Planck Gesellschaft Archive (MPG Archive) III/71/127-2, "Atomprofessor: Kernkraftwerk ist gefährlicher als sein Ruf," Neue Westfälische, Dec. 19, 1967.
} 


\section{Radium Pillows and Radium Water: Consumer Goods as a Public Health Danger}

In December 1965, Prof. W. Seelentag of the West Berlin Public Health Office wrote to the Federal Health Ministry that he had "heard of two cases of possible radiation damage from socalled 'radium compresses' ... The public needs to be told that they should not ... use these compresses, and ... they should report them to the proper authorities." ${ }^{111}$ By March 1966, Seelentag reported that he now knew of six such cases. In the early 1960s, regional health officials and dermatologists began identifying patients with carcinomas from long-term use of radioactive compresses, radioactive pillows, or other over-the-counter radioactive therapies. ${ }^{112}$ In 1966, Dr. Willi Born of the University of Freiburg Dermatology Clinic wrote in the Deutsches Ärzteblatt, "Recent observations reveal a wave of unintentionally selfinflicted carcinomas with horrifying clarity." Most over-the-counter radioactive therapies had been illegal since the First Radiation Protection Law of $1960 .{ }^{113}$ But, Born continued, although such therapies could produce radioactive exposures up to a thousand times higher than the legal limits set in 1960, they remained at large: "What has happened to the countless [radioactive] preparations? As unbelievable as it sounds: Nothing! The radium has remained uncontrolled in the hands and homes of consumers, perhaps still in active use, perhaps passed along, set aside, forgotten, or thrown away-dangerous not only for the owner, but also for many others. Forgotten also by officials obliged to carry out the radiation protection law?"114 Dr. Born demanded that the government educate the public and rid the country of radium pillows, compresses, and similar products. Other physicians, organizations such as the pharmaceutical commission of the German Congress of Physicians, and state health authorities joined Born, calling attention to an urgent public health threat. ${ }^{115}$ Between 1965 and 1968, state public health officials launched media campaigns to alert the public to the dangers of radioactive health aids, to halt their use, and to collect as many as possible.

The campaign to eradicate popular radiation therapies focused on changing public perceptions. Over-the-counter "radium" therapies - from radium water, butter, and beer, to pills, tinctures, insoles, cosmetics, pillows, and compresses- had emerged across Europe and North America in the 1910s and 1920s, building on the popularity of radium spas, which claimed that naturally radioactive water cured a multitude of ills. ${ }^{116}$ Doctors also embraced radioactive products in their therapeutic arsenals. Although the medical literature and the press questioned the safety of these therapies in the 1930s, and their use seemed to

\footnotetext{
${ }^{111}$ BArch Koblenz, B 142 No. 1749: 198-99, letter from Prof. Seelentag (Bundesgesundheitsamt Berlin) to BM Gesundheit, Dec. 7, 1965.

${ }^{112}$ BArch Koblenz, B 142 No. 1749: 213, 215, 217, 349; BayHStA, MInn 111277, "Spätschäden durch 'Radium-Kompressen' von Hausierern,"' Aktuelle Medizin, Feb. 18, 1966.

${ }^{113} \mathrm{Spa}$ treatments and naturally radioactive water were not banned.

${ }^{114}$ BArch Koblenz, B 142 No. 1749: 224; Willi Born, "Schwere lebensbedrohende Schäden durch in Haushalten vergessenes Radium,” Deutsche Ärzteblatt no. 13 (March 26 ,1966): 857.

${ }^{115}$ BArch Koblenz, B 142 No. 1749: 251, letter from Dr. Born to Dr. Krebs (BM Gesundheit), June 18, 1966.

${ }^{116}$ Murdock "Selling Scientific Authority," 24-25; Lavine, The First Atomic Age, 89, 101-13; Maria Rentetzi, "Packaging Radium," 381-96; BArch Koblenz, B 142 No. 1749: 172, press release, Arbeitsund Sozialministerium Baden-Württemberg, Dec. 9, 1968. Many products were made with radioactive materials other than radium.
} 
fall off thereafter, they remained widely accepted, advertised, and unregulated through the 1950s. ${ }^{117}$

It seems impossible that people using these therapies for decades suddenly developed cancers only in the 1960s. Dr. Born noted that physicians had treated a case that appeared in the medical literature in 1954 as anomalous. ${ }^{118}$ Most doctors, like lay people, did not expect radioactive therapies to be dangerous, and because problems developed long after initial exposures, they were slow to connect the dots. These therapies had mainstream status, as illustrated by cases that came to health officials' attention in the 1960s. One physician wrote in 1965 to Prof. Seelentag of the Federal Public Health Office in Berlin, explaining that his parents had given him a radium compress in 1951 to treat his asthma, and that he had worn it for five years. The package insert asserted that it had "no damaging side effects." But, in 1961, he developed dermal discoloration, hyperkeratosis, and ulcerations. After consulting with dermatologists, having basal cell carcinomas removed, and discovering people with similar problems, he turned to public health authorities for advice. ${ }^{119}$ Another patient bought a radium pillow in 1953 and used it for six years - reassured by the company's claims that chronic use was safe. After developing metastatic carcinomas, he sued the manufacturer. The court showed little sympathy. Radiation health experts linked the cancers to the pillow, but the court relied on information from the Munich Balneological Institute, which disputed the idea that radium pillows were dangerous. Even if the pillow had caused the cancers, said the court, the manufacturer could not have known the risk in 1953. Dr. Born considered "such ignorance" "pathetic." ${ }^{20}$ He told federal health authorities that decades of medical experience had demonstrated that these products could be dangerous, and that district attorneys should defend consumers against these companies' misleading information. ${ }^{121}$ Yet, people still believed the products were safe and effective.

The 1960 radiation protection law outlawed the manufacture and sale of most radioactive products, and it required permits for companies producing radioactive prescription treatments and for physicians prescribing them. ${ }^{122}$ In 1962, further legislation limited the production and sale of pharmaceuticals containing radioactive materials or treated with

\footnotetext{
${ }^{117}$ Murdock, "Selling Scientific Authority," 40; BArch Koblenz, B 142 No. 1749: 224, Born, "Schwere lebensbedrohende Schäden," 857-58; MPG Archiv, I/10/5I, letter from Institut für Medizinische Biologie (Berlin) to Uni Hautklinik Münster Dr. Graul, Jan. 12, 1953; MPG Archiv, I/10/5I, advertisement for "RAN” Heil Kissen, 1951/1952; advertisement for Radium Trinkkur, Passauer Neue Presse, Feb. 1, 1949; advertisement for Radium Trink- und Bade Apparat, Radiumtrink Röhrchen, Radium Kompresse, Passauer Neue Presse, Feb. 22, 1949; advertisement for Bad Trissl Radiumsalz Passauer Neue Presse, Sept. 3, 1949.

${ }^{118}$ BArch Koblenz, B 142 No. 1749: 198, letter from Dr. Seelentag (Bundesgesundheitsamt Berlin) to BM Gesundheit, Dec. 7, 1965, and Dr. Born lecture "Krebs durch radioaktiver Hausmittel," Oct. $29,1966$.

${ }^{119}$ BArch Koblenz, B 142 No. 1749: 217, letter from Dr. Leonards to Prof. Seelentag (Bundesgesundheitsamt Berlin), Nov. 11, 1965.

${ }^{120}$ BArch Koblenz, B 142 No. 1749: 224, Born, "Schwere lebensbedrohende Schäden,” 858.

${ }^{121}$ BArch Koblenz, B 142 No. 1749: 219-20, letter from Dr. Born to Bundesgesundheitsamt, Abt Strahlenschutz, Berlin (Prof. Seelentag), July 8, 1965.

122 "Erste Verordnung über den Schutz vor Schäden durch Strahlen radioaktiver Stoffe (Erste Strahlenschutzverordnung) vom 24 Juni 1960," Bundesgesetzblatt (1960), Pt. I; BArch Koblenz, B 142 No. 1749: 198, letter from Prof. Seelentag to BM Gesundheit, Dec. 7, 1965. West Berlin outlawed these products in 1958; see BArch Koblenz, B 142 No. 1749: 177, "Warnung vor Radium-Heizkissen" (unidentified 1968 clipping from a Berlin magazine article).
} 
radiation. ${ }^{123}$ Some state governments had already warned the public about the health risks of popular radiation therapies in 1958-1959. More did so in the early 1960s, in response to the new laws. But, as warnings were often buried in the back of newspapers, public perceptions changed slowly. ${ }^{124}$ After the new law, public health authorities received only a slow trickle of radiation products. ${ }^{125}$

Health authorities' efforts to eradicate popular radioactive therapies challenged the Federal Republic's hands-off approach to many aspects of public health. Anti-radiation advocates pushed federal and state governments to embrace preventive medicine, limit medical and pharmaceutical practice to qualified practitioners, hold businesses responsible for creating health risks, and educate citizens about health threats. Failing to provide victims with government support would be a "failure of the state's duty to protect its citizens and their health," said Dr. Born. ${ }^{126}$

In 1967, the federal government tackled the problem in earnest. The Health Ministry asked states to warn the public about radioactive therapies and to collect radium compresses, emanators, salves, pillows, slippers, shoe inserts, pain pills, and drinking cups across the country. They issued official statements and pamphlets, and they asked the media to spread the word. ${ }^{127} \mathrm{~A}$ rash of sensational television specials, radio broadcasts, and news stories calculated to frighten ordinary citizens followed. As one magazine declared, "anyone who took a Geiger counter to a farm in lower Bavaria would be in for a surprise. The device ticks ... There is a radium pillow or a radium cup right in the bedroom." 128 Another warned: "radiation death lurks in drawers ... in cupboards, and on night tables." It is easy to "drink innocently" from the cup "that grandma bought thirty years ago," little suspecting that one was "sowing the seeds for cancer." West Germans opened their newspapers to read: "Radium Warning! Deadly danger," "Radiation death lurks in households!" "Deadly rays in Berlin homes," "Radium rich 'Heilmittel' endangers health!" "Patient suffocates in atomic pillow," "Death crept into households by mail order," and

\footnotetext{
123 "Verordnung über die Zulassung von Arzneimitteln, die mit ionisierenden Strahlen behandelt worden sind oder die radioaktive Stoffe enthalten, vom 29 Juni 1962,” Bundesgesetzblatt no. 24 (July 12, 1962): 439.

${ }^{124}$ BArch Koblenz, B 142 No. 1749: 177, "Warnung vor Radium-Heizkissen”; BArch Koblenz, B 142 No. 1749: 331, press release, Staatliche Pressestelle Hamburg, Nov. 28, 1966; BArch Koblenz, B 142 No. 1749: 174, letter from Bayerische Staatsministerium des Innern (Bayr. MInn) to BM Gesundheit, June 27, 1969; letter from Hessischer Minister für Arbeit, Volkswohlfahrt und Gesundheitswesen to BM Gesundheit, June 25, 1969; BayHStA, MInn 111277, letter from Dr. Pohl (Bayr. MInn) to Dr. Born, University of Freiburg, Nov. 14, 1966; BayHStA, MInn 111277, letter from Berta Mühlstrasser to Ministerialdirigent Dr. Illig, June 12, 1960.

${ }^{125}$ BayHStA, MInn 111277, letter from Dr. Moos, Regierung von Oberbayern, to Bayr. MInn, Aug. 29, 1960; BayHStA, MInn 111277, letter from Dr. Pohl (Bayr. MInn) to Dr. Born (University of Freiburg), Nov. 14, 1966.

${ }^{126}$ BArch Koblenz, B 142 No. 1749: 57, Karl Bechert, "Warnung aus den USA," SPD Pressedienst, July 22, 1968; BArch Koblenz, B 142 No. 1749: 491, letter from Dr. Gerhard Breitkopf to BM Gesundheit, Nov. 29, 1970; BArch Koblenz, B 142 No. 1749: 251-55, letter from Dr. Born to Dr. Krebs (BM Gesundheit), June 18, 1966.

${ }^{127}$ BArch Koblenz, B 142 No. 1749: 263-64, letter from Bundesminister für Wissenschaftliche Forschung to BM Gesundheit, April 4, 1967; BArch Koblenz, B 142 No. 1749: 162, 169, 172, 174, 176. Some press coverage began in 1966.

${ }^{128}$ BArch Koblenz, B 142 No. 1749: 161, "Hausmittel Radium?” (unidentified magazine article), May $19,1969$.
} 
"Radium 'therapies' make you sick, not healthy." 129 News reports and public service messages urged people to surrender these therapies to authorities and to see a doctor if they had used them. ${ }^{130}$ They drew an explicit link between cancer and radioactive consumer goods that never before had been publicly associated with cancer. ${ }^{131}$

Media reports of dire health effects from radioactive therapies caught the public's attention. People began to surrender such goods to public health officials and to seek medical exams for radiation damage. ${ }^{132}$ Not all of them understood which products were dangerous. Some radioactive pillows and drinking cups were poorly marked or had lost their labels. Citizens conflated electric blankets, infrared lamps, vibrating pillows, and other nonradioactive gadgets with truly radioactive products. ${ }^{133}$ State offices were unprepared to handle and store hazardous waste, so public health officials had to manage the objects they collected. ${ }^{134}$ The public, it seemed, had realized that popular radioactive therapies were dangerous. But the government's ability to protect public health in the radioactive age remained a work in progress.

\section{Narratives of Radiation Danger Converge}

The West German government, scientists, and medical professionals had long treated atomic fallout, popular radioactive therapies, medical treatment, X-rays, and occupational exposures separately, a tendency exacerbated by health and radiation policy fragmented across multiple state agencies. Government campaigns against popular radioactive therapies avoided mentioning non-medical radioactive products to avoid public "confusion." 135 They also ignored contemporaneous debates about atomic fallout or nuclear power.

Citizen inquiries in 1968-1969 nevertheless suggest that many people now believed that radiation—from any source — could be a health threat. Helene K.'s letter to the Max Planck Institute was not anomalous. ${ }^{136}$ Others also told authorities that radiation had harmed them. Richard W., for example, asked the Health Ministry for treatment of a ten-year old

\footnotetext{
${ }^{129}$ BArch Koblenz, B 142 No. 1749: 176, 177-178, 185, 331, "Radium Warnung! Tödliche Gefahr durch 'Medikament'-Heizkissen," Der Abend, Dec. 21, 1968; "Warnung vor Radium-Heizkissen," 1968; press release by Sozialminister Niedersachsen, April 14, 1969; press release by Amt für Arbeitsschutz Hamburg, Nov. 28, 1966.

${ }^{130}$ BArch Koblenz, B 142 No. 1749: 418, 422, "Warnung vor Radium-Heilmitteln," Westfälische Rundschau, July 17, 1968; "Radium 'Heilmittel' machen krank statt gesund,” Rheinische Post, July 19, 1968.

${ }^{131}$ BArch Koblenz, B 142 No. 1749: 172, press release by Arbeits- und Sozialministerium BadenWürttemberg, Dec. 9, 1968; BArch Koblenz, B 142 No. 1749: 349-51, lecture by Dr. Born, Oct. 29, 1966. On German ideas about cancer, see Robert N. Proctor, The Nazi War on Cancer (Princeton, NJ: Princeton University Press, 1999).

${ }^{132}$ BArch Koblenz, B 142 No. 1749: 331, press release by Staatliche Pressestelle Hamburg, Nov. 28, 1966; BArch Koblenz, B 142 No. 1749: 349-51, lecture by Dr. Born, Oct. 29, 1966.

${ }^{133}$ BArch Koblenz, B 142 No. 1749: 331, press release by Staatliche Pressestelle Hamburg, Nov. 28, 1966; BArch Koblenz, B 142 No. 1749: 183, letter from Niedersächsischer Sozialminister to BM Gesundheit, Aug. 18, 1969.

${ }^{134}$ BArch Koblenz, B 142 No. 1749: 158-59, letters between BM Gesundheit and Minister für Arbeit, Sozialordnung und Gesundheitswesen des Saarlandes, Feb. 25, 1969 and March 14, 1969; BArch Koblenz, B 142 No. 1749: 177, "Warnung vor Radium-Heizkissen."

${ }^{135}$ BayHStA, MInn 111277, letter from Bundesminister für Wissenschaftliche Forschung to Strahlenschutz zuständigen Minister der Länder, April 4, 1967.

${ }^{136}$ BArch Koblenz, B 142 No. 1749: 100-103, letter from Helene K. to Max Planck Institut für Biophysik, Sept. 30, 1969.
} 
"radioactive burn" on his hand. He "confirmed" radiation damage by holding a Geiger counter against his hand. Having never worked with radioactive materials, he believed that the problem stemmed from radioactive rain following hydrogen bomb tests in 1954. ${ }^{137}$ Wilhelm S. similarly complained that a 1957 X-ray had damaged his health. ${ }^{138}$ One writer asked whether his luminous watch was dangerous. ${ }^{139}$ Another thought his wife's tour of a particle accelerator had caused their child's Down syndrome. ${ }^{140}$ In 1968, American reports claiming that rings made of gold used in radiation medical treatments had caused carcinomas sparked popular concerns - and questions in the Bundestag-about jewelry safety. ${ }^{141}$

The 1950s and 1960s constituted a distinct period in the Federal Republic's "Radioactive Age." By the late 1960s, West German citizens believed that nuclear radiation offered threats and opportunities in many areas of life-military, civilian, environmental, occupational, and medical. Despite official efforts to treat sources of radiation separately, citizens concluded that warnings about fallout and popular therapies raised questions about occupational safety and nuclear power. Citizens' specific claims of radiation danger were sometimes implausible, but their fears should not be dismissed as irrational. Radiation health risk was supported by science, press coverage, international organizations, and state public health initiatives. Citizens demanded broad protections from radiation-ranging from safe food, water, consumer goods, and work conditions to personal health problems.

Popular demands and state responses to public "neuroses" illustrate that anxiety and perceived instability were integral, even productive, elements in the Federal Republic through the 1960s. The absence of mass protest was not proof of steady stabilization, as scholars often assume. ${ }^{142}$ Citizens articulated their unease in shifting and varied ways, from concerns about fallout to questions about luminescent watches. Such diversity has obscured the degree to which those fears - and the anxieties they awakened in state actors - persisted through the 1960s.

Politicians and government officials gradually learned not to ignore popular worries. International agreements spurred domestic radiation protection and lent an air of rationality to radiation fears. But state actors also responded to citizens' concerns as they discovered that government transparency eased public distrust and won broader acceptance of nuclear power-at least for a time. This apparent convergence of grassroots action and government engagement reflected a degree of democratization and technological and political rationalization-key elements to the Federal Republic's success, according to established narratives. By 1970, the Federal Republic had made radiation safety measures integral to many aspects of its law and administration. Such successes were real, but by no means linear or complete. Incremental changes in policy and in public discussion ultimately raised more questions

\footnotetext{
${ }^{137}$ BArch Koblenz, B 142 No. 1749: 15, letter from Richard W. to BM Gesundheit, April 5, 1968.

${ }^{138}$ BArch Koblenz, B 142 No. 1749: 76, letter from Wilhelm S. to BM Gesundheit, May 5, 1969; also see BArch Koblenz, B 142 No. 1749: 108, letter from Ernst P. to BM Gesundheit, Nov. 4, 1969.

${ }^{139}$ BArch Koblenz, B 142 No. 1749: 139, note from Kohler, Nov. 25, 1969.

${ }^{140}$ BArch Koblenz, B 142 No. 1749: 149-150, 153, correspondence between Kurt N. and BM Gesundheit, Nov. 17, 1969.

${ }^{141}$ BArch Koblenz, B 142 No. 1749: 439, parliamentary questions, Oct. 21, 1968; BArch Koblenz, B 142 No. 1749: 457, BM Gesundheit, “Gesundheitspolitik aus erster Hand” Press Release no. 38 (Oct. 28, 1968).

${ }^{142}$ Wehler, Deutsche Gesellschaftsgeschichte, 61.
} 
than they settled. Fear of nuclear war, the expansion of nuclear power, and questions about nuclear waste disposal produced widespread anti-nuclear and environmental activism in the 1970s and 1980s. In the Federal Republic, safety, stability, and freedom from fear remained elusive goals for state and society alike.

California State University, Long Beach 